\title{
Validation of Scientific-Based Physics Learning Modules to Improve Critical Thinking Skills in Dynamic Fluid Materials
}

\author{
Alpi Zaidah ${ }^{1}$, Ermila Mahariyanti ${ }^{1}$ \\ 1 Institute Pendidikan Nusantara Global \\ 07 Aik Mual, Praya, Central Lombok, 83511, Indonesia
}

DOI: $10.22178 /$ pos. $65-5$

LCC Subject Category: LB2300-2430

Received 16.11.2020

Accepted 20.12.2020

Published online 31.12.2020

Corresponding Author:

Alpi Zaidah

hamidi@unram.ac.id

(C) 2020 The Authors. This article

is licensed under a Creative

Commons Attribution 4.0 License

(c) (1)

\begin{abstract}
This study aims to obtain a valid scientific-based physics learning module to improve critical thinking skills in Dynamic Fluid material for high school/MA students. This study uses a research development design and approach or is included in development research. In this study, a scientificbased physics learning module was developed. The development of this module refers to the development of the (4-D model) proposed by Thiagarajan. This model consists of 4 development stages, namely (Define, Design, Develop, and Disseminate). However, this study is only limited to the development stage, namely the validation stage. The validation test is a theoretical validation. Namely, assurance carried out by experts in their fields. The confirmation includes material, media, language, teacher and peer validation. The research results found that the physics-based learning module was scientifically based on improving critical thinking skills in Dynamic Fluid material for high school / MA students, which were developed to meet the validity criteria.

In conclusion, the physics-based learning module to improve critical thinking skills in Dynamic Fluid material for high school / MA students is very well developed.
\end{abstract}

Keywords: Physics Learning Module; Scientific; Critical Thinking Skills.

\section{INTRODUCTION}

The development of technology and information in the 21st century develops rapidly, which changes human life patterns and impacts education. In education development, students must have critical thinking skills, communication, leadership, collaboration, adaptability, productivity and accountability, innovation, the ability and spirit of entrepreneurship, and access and analyze information [2]. Curriculum 2013 is a curriculum that can improve and balance soft skills and hard skills attitudes, skills and knowledge [7]. Therefore, education needs to be implemented optimally to produce quality graduates to face future challenges.

The learning approach used in the 2013 curriculum is scientific. Author [10] learning with a scientific method has the following characteristics: student-centred involves scientific process skills in constructing concepts, laws or principles, involves cognitive processes that can stimulate intellectual development, especially high-level skills, and can develop student character.
Critical thinking is the essential part and is very hotly discussed by scientists from both the education and general fields. Authors $[6,12]$ state that critical thinking is an activity such as interpretation, analysis, concluding, evaluation, explaining and self-regulation. The scientific learning process is expected to improve the necessary thinking skills to create productive, creative, and innovative students. This is consistent with [1] said that the scientific approach significantly affects learning outcomes by controlling critical thinking skills. The study conducted by the author [16]. Concluded that scientific learning in the learning process makes the learners work together more collaboratively, more active participation, and educating more students are student-centred.

Learning is a process of interaction between teachers and students and with students to acquire new knowledge supported by various media, learning resources and methods that suit their needs [7]. So learning is a reciprocal relationship between teachers and students and relationships among students using multiple learning resources 
and models to acquire knowledge. Learning activities should involve all the psychophysical aspects of students both physically and spiritually so that behaviour changes can occur quickly and correctly, both related to learning, attitudes and skills [9].

Learning resources and media that is not optimal makes student learning outcomes less, so we need a medium to foster interest and a new learning atmosphere to increase students' interest and critical thinking skills, namely by developing teaching materials. The teacher needs teaching materials as information, tools, or texts useful for planning and studying learning [8]. One of the teaching materials that can be developed is a module.

The learning module is the smallest unit of teaching and learning programs studied by students individually or taught by themselves self-instructional [21]). According to [21] Modules are printed teaching materials designed to be reviewed independently by learning participants. Modules are also called media for independent learning because they are equipped with selfstudy instructions that students can understand [11]. Research [17] that approach with modules provides flexibility for distance learning for learners. Learning modules will be more effective because they can understand the individual, small group, and large group. The module has the advantage that the students can learn and for learners to evaluate their learning results.

The currently developed modules must be closer to the learning approach used in the 2013 curriculum, namely the scientific method. A scientificbased physics learning module was designed on dynamic fluid material for class XI high school students based on this background.

\section{METHODS}

The research was conducted at MA Cendekia NW Aiklomak, East Lombok. The research and development model used is the 4D model developed by [20]. The 4D stage consists of the define, design, develop, and disseminate stages. This paper reviews the Develop stage, namely revising the initial draft of teaching materials (modules) that have been compiled at the design stage. Revisions are based on a validation process carried out by material experts, media experts, linguists, teachers and peer reviews. Each validator is an expert in their field with a minimum educational qualification of S2. Research instruments at the Develop stage are module validation sheets by material experts, module validation sheets by media experts, module validation sheets by linguists, module validation sheets by teachers and module validation sheets by peer reviews or peers. Qualitative descriptive data analysis is used to process qualitative data in the form of suggestions, criticisms, and comments from the validators. The study was carried out by classifying and describing the qualitative information obtained from the expert validation sheet. The data will be converted in percentage form using the following formula (Table 1).

Table 1 - The modified Likert Scale Validity Criteria

\begin{tabular}{|c|c|}
\hline Persentase & Criteria \\
\hline $0-20$ & Bad \\
\hline $21-40$ & Not bad \\
\hline $41-60$ & Pretty good \\
\hline $61-80$ & Good \\
\hline $81-100$ & Very good \\
\hline
\end{tabular}

Source: [13]

The final assessment of module validation results was adapted to [18] with Natural cut off. The assessment results are the validation results by material experts, media experts, linguists, teachers, and peer reviews. If the average score of the assessment results is greater than the lower limit score, it can be concluded that it is feasible to use.

\section{RESULTS AND DISCUSSION}

This research was conducted to produce a scientific-based SMA / MA class XI physics module on dynamic fluid material. This printed module is arranged following the core competencies and necessary competencies according to the 2013 curriculum. The module is equipped with scientificbased module learning activities that can direct students to scientific steps with five learning steps (5M), including observing, asking, trying, reason, and communicating. To attract students' interest and motivation, the module is equipped with pictures, illustrations and writing language that is also easy to understand. The development of scientific-based learning modules is based on 4-D modules: Define, Design, Develop, and Disseminate.

There are two essential criteria in developing a module: validation of the module's contents and benefits after being tested [14]. Authors [15] stated that doing a module required a content 
validation process and limited trials with the subject real. This study focuses on module validation testing before it is tested on real subjects. Validation is carried out on the developed module draft I to determine the feasibility of using the module. According to [4], verification is done by asking for help from experts who master the studied competencies. Product trial data includes data on the material expert module's validation results, media expert, linguist, physics teacher, and peer review. The results of the expert validation can be seen in Table 2.

Table 2 - Module Validation Results

\begin{tabular}{|c|c|c|c|}
\hline No & Validator & Ideal Percentage & Category \\
\hline 1 & Material Expert & 93 & Very good \\
\hline 2 & Media Expert & 98 & Very good \\
\hline 3 & Language Expert & 88 & Very good \\
\hline 4 & Teacher & 90 & Very good \\
\hline 5 & Teacher & 91 & Very good \\
\hline 6 & Teacher & 90 & Very good \\
\hline 7 & Peer Review & 86 & Very good \\
\hline 8 & Peer Review & 93 & Very good \\
\hline
\end{tabular}

Based on the validation results in Table 2, an analysis of the cut-off calculation is then carried out to determine the module's feasibility.

The math shows that the assessment's average value is more than the cut off value $(92>91)$.

It can be concluded that the module is suitable for use as teaching material in learning physics. Some suggestions from the validator are presented in Table 3.

Tabel 3 - Suggestion and Revised result from the validator

\begin{tabular}{|l|l|l|}
\hline No & \multicolumn{1}{|c|}{ Suggestion } & \multicolumn{1}{c|}{ Revision I } \\
\hline \multicolumn{3}{|c|}{ Linguist Validator (Content Eligibility) } \\
\hline 1 & $\begin{array}{l}\text { Some pictures not } \\
\text { available with the } \\
\text { source image }\end{array}$ & $\begin{array}{l}\text { A picture that has not } \\
\text { given a source has } \\
\text { been shown an image } \\
\text { source }\end{array}$ \\
\hline 2 & $\begin{array}{l}\text { Several phenomena are } \\
\text { replace }\end{array}$ & $\begin{array}{l}\text { The phenomena have } \\
\text { been replaced } \\
\text { according to the } \\
\text { suggestion }\end{array}$ \\
\hline 3 & $\begin{array}{l}\text { Some grammar is not } \\
\text { correct }\end{array}$ & $\begin{array}{l}\text { Grammar has been } \\
\text { corrected according to } \\
\text { the suggestion }\end{array}$ \\
\hline
\end{tabular}

\begin{tabular}{|c|c|c|}
\hline No & Suggestion & Revision I \\
\hline \multicolumn{3}{|c|}{ Linguist Validator (Language Eligibility) } \\
\hline 1 & $\begin{array}{l}\text { Still found some word is } \\
\text { not suitable with EYD } \\
\text { (Improved Spelling) }\end{array}$ & $\begin{array}{l}\text { Words that are not } \\
\text { suitable with EYD have } \\
\text { been corrected }\end{array}$ \\
\hline 2 & $\begin{array}{l}\text { There are still incorrect } \\
\text { punctuation mark }\end{array}$ & $\begin{array}{l}\text { The wrong } \\
\text { punctuation has been } \\
\text { corrected according to } \\
\text { the suggestion }\end{array}$ \\
\hline 3 & $\begin{array}{l}\text { Use of Capital and Non- } \\
\text { Capital alphabet not } \\
\text { perfect }\end{array}$ & $\begin{array}{l}\text { Correction of Capital } \\
\text { and non-Capital } \\
\text { alphabet have been } \\
\text { corrected }\end{array}$ \\
\hline \multicolumn{3}{|c|}{$\begin{array}{l}\text { Media Expert Validator (Graphic and } \\
\text { Presentation Eligibility) }\end{array}$} \\
\hline 1 & Table no lines & $\begin{array}{l}\text { The table is added } \\
\text { lines }\end{array}$ \\
\hline 2 & $\begin{array}{l}\text { Glosarium was moved } \\
\text { to the front after the } \\
\text { preliminary }\end{array}$ & $\begin{array}{l}\text { The location of } \\
\text { Glosarium have been } \\
\text { moved to the front }\end{array}$ \\
\hline \multicolumn{3}{|c|}{ Peer Review } \\
\hline 1 & $\begin{array}{l}\text { Consistency of writing } \\
\text { is concerned (we, you, } \\
\text { us) }\end{array}$ & $\begin{array}{l}\text { Consistency writing } \\
\text { (you) }\end{array}$ \\
\hline 2 & $\begin{array}{l}\text { Use of Affixes there are } \\
\text { still not suitable }\end{array}$ & $\begin{array}{l}\text { Use of Affixes has been } \\
\text { fixed }\end{array}$ \\
\hline \multicolumn{3}{|c|}{ Reviewer } \\
\hline 1 & $\begin{array}{l}\text { In Practicum (Learning } \\
\text { Activities I, II and III) } \\
\text { expected that the tools } \\
\text { and materials and } \\
\text { procedures are } \\
\text { adjusted according to } \\
\text { experiments result }\end{array}$ & $\begin{array}{l}\text { In Practicum (Learning } \\
\text { Activities I, II, III) the } \\
\text { tools and materials } \\
\text { and procedures have } \\
\text { been adjusted } \\
\text { according to } \\
\text { experiments result }\end{array}$ \\
\hline
\end{tabular}

Based on table 3, a revised draft I module was produced according to suggestions from validators, teachers and peers. The resulting scientific-based physics module is suitable for use in learning in class XI SMA / MA. Through this module, students can study independently because students can study anywhere and anytime. The material in the module is by the 2013 curriculum and is based on scientific learning.

\section{CONCLUSION}

Physics-based scientific learning module to improve critical thinking skills on the theme of dynamic fluids is a learning module developed based on scientific-based learning syntax. The module is said to be feasible because it has gone through several feasibility tests. Based on the feasibility test, the module is categorized as possible, which is supported by calculation results that show an 
average value of 92 more significant than the cut off assessment of 91.

Based on the research results, several suggestions are proposed, namely: 1) The scientific-based physics learning module that has been developed can be used as a reference for developing modules on other materials by considering the needs and characteristics of students; 2) students who are sampled should be given a clear understanding of scientific-based learning; 3) schools should provide learning support facilities such as laboratories that can support teachers in implementing physics-based physics learning modules, and 4) the deficiencies and imperfections of the modules/products that have been produced should be used as insights to develop even better products.

\section{ACKNOWLEDGEMENT}

This writing gets a lot of help for writers. Therefore, thank you, especially to Mr Dr A. Thalib, MA as Rector of the Global Nusantara Institute of Education.

\section{REFERENCES}

1. Asta, I., Agung, A., Widiana, I. (2015). Pengaruh pendekatan saintifik dan kemampuan berpikir kritis terhadap hasil belajar IPA. EJournal PGSD Universitas Pendidikan Ganesha, 3(1), 1-10.

2. Barry, M. (2012). What skills will you need to succeed in the future? Retrieved from https://visual.ly/community/Infographics/business/what-skills-will-you-need-succeed-future

3. Daryanto. (2013). Menyusun Modul. Yogyakarta: Gava Media.

4. Depdiknas. (2008). Teknik Penyusunan Modul. Jakarta: Direktorat Jenderal Manajemen Pendidikan Dasar dan Menengah.

5. Facione, P. A. (2015). Critical thinking: what it is and why it counts. Retrieved from https://www.researchgate.net/publication/251303244_Critical_Thinking_What_It_Is_and_Why_ It_Counts

6. Fadlillah. (2014). Implementasi Kurikulum 2013 Dalam Pembelajaran SD/MI, SMP/MTs, \& SMA/MA. Yogyakarta: Ar-Ruzz Media.

7. Hamdani. (2011). Strategi Belajar Mengajar. Bandung: CV Pustaka Setia.

8. Hanafiah dan Cucu Suhana. (2012). Konsep Strategi Pembelajaran. Bandung: Refika Aditama.

9. Cecily, H., \& Omoush, A. (2014). Efficacy of Problem Based Learning (PBI) Over Lecture Method in Enhancing the Critical Thinking Skills and Problem Solving Ability Among Nursing Students in KSA. International Journal of Educational Science and Research, 4(5), 1-8.

10. Hosnan, M. (2014). Pendekatan saintifik dan kontesktual dalam pembelajaran abad 21. Bogor: Ghalia Indonesia.

11. Prastowo, A. (2014). Pengembangan Bahan Ajar Tematik: Tinjauan Teoritis dan Praktik. Jakarta: Kencana.

12. Ryberg, Th. (2010). Implementation of Scientific Approach for Activities Laboratory. Journal Paedagogy, 32, 45-68.

13. Ricketts, J. D., \& Rudd, R. D. (2005). Critical Thinking Skills of Selected Youth Leaders: The Efficacy Of Critical Thinking Dispositions, Leadership, And Academic Performance. Journal of Agricultural Education, 46(1), 32-43. doi: 10.5032/jae.2005.01032

14. Riduwan. (2012). Skala Pengukuran Variabel-Variabel Penelitian. Bandung: Alfabeta. 
15. Rozubi, N., Poh Li, L. (2015). The Development of Psychological Well-Being Programme Based on Six Factormodel Psychological Well-Being RYFF (1989). International Journal of Information Research and Review, 2(9), 1176-1180.

16. Russel, J. D., \& Johanningsmeier, K. A. (1981). Improving competence through modular instruction. USA: Kendall-Hunt Publishing Company.

17. Sejpal, K. (2013). Modular Method of Teaching. International Journal for Research in Education, 2(2), 169-171.

18. Sugiyono. (2015). Metode Penelitian dan Pengembangan (Research and Development. Bandung: Penerbit Alfabeta.

19. Thiagarajan, S. (1974). Instructional Development for Training Teachers of Exceptional Children. Minesota: Indiana University.

20. Septiani, W. (2009). Pendekatan Kombinasi Metode AHP dan Metode Cut Off Point pada Tahap Analisis Keputusan Perancangan Sistem Informasi Penjualan PT. X. Undip: Jurnal Teknik Industri, 4(3), 195-204.

21. Winkel, W. (2009). Psikologi Pembelajaran. Yogyakarta: Media Abadi. 